Journal of Finance \& Banking Studies 5 (5), 2016: 16-29

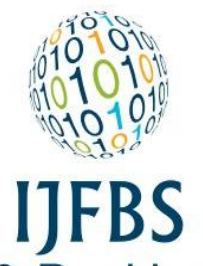

Finance \& Banking Studies

\section{Finans ve Bankacılık Çalışmaları Dergisi}

IJFBS, CILT 5 SAYI 5, Özel Sayı ISSN: 2147-4486

Contents available at www.ssbfnet.com/ojs

Doi: 10.20525/ijfbs.v5i5.661

\title{
Adli Muhasebecilik Mesleği ve Mesleğin Geleceği Saime DOĞAN
}

Uygulamalı Bilimler Yüksekokulu, Bankacılık ve Finans Bölümü, Öğretim Görevlisi, Kırklareli Üniversitesi

\section{Özet}

Küreselleşme ve teknolojik gelişmeler sonucunda işletme faaliyetlerinin çeşitlenmesi ve karmaşık bir yapıya dönüşmesi hile ve yolsuzlukların araştııılması ve ortaya çıkarılmasında yargı mensupları veya suç bilimi araştırmacılarının yetersiz kalmasına yol açmıştır. Özellikle 21. yüzyılda yaşanan şirket ve denetim skandalları, finansal raporlamaya olanın güvenin sarsılmasına, muhasebe ve denetim işlevlerinin yeniden gözden geçirilmesine bu da işletmelerde yeni bir uzmanlık alanı olan adli muhasebecilik mesleğinin ortaya çıkmasına neden olmuştur. Adli muhasebeciler, hukuki süreçle muhasebe süreci arasında köprü görevi yürüterek, hata ve hilelerin tespit edilmesi ve sonrasında davalara destek olma açısından önemli bir role sahiptirler.Bu çalışmanın amacı adli muhasebe ve adli muhasebecilik kavramlarını açıkladıktan sonra, adli muhasebe mesleğinin mevcut durumu ve geleceğine yönelik bilgi vermektir.

Anahtar Kelimeler: Adli Muhasebe, Adli Muhasebecilik, Denetim, Hile.

Jel Sınıflandırması: K22, M41, M42

\section{Forensic Accountancy and The Future Of The Profession}

\section{Abstract}

As a result of globalisation and technological developments, the business activities were divesified and had a complex structure. Thus the members of judiciary or criminal scientists in the investigation and uncovering of fraud and corruption were insufficient. Especially, fraud and corruptions taking place in the 21st century led to the confidence in financial reporting to be shaken, accounting and auditing functions to be revised, as a result new areas of expertise such as forensic accountancy emerged. Forensic accountants have an important role in terms of detection of fraud and error and later to support the court case by conducting bridge between the accounting process and legal process. The purpose of this study is introducing and explaining the present situation and future of the forensic accountancy frofession after explaining the forensic accounting and forensic accountancy concepts.

Keywords: Financial Forensic Accounting, Forensic Accountancy, Audit, Fraud. JEL Classification : K22, M41, M42 


\section{Giriş}

Bilgi toplumu sürecinin yaşandığı günümüzde, toplumun bir parçası olan işletmeler, yaşanan değişim karşısında ayakta kalabilmek ve varlıklarına devam ettirebilmek için teknolojik değişimlere ayak uydurmaya çalışmaktadırlar. Küreselleşme olarak adlandırılan bir ortamın yaratılmasıyla, uluslar arası şirketlerin artmasıyla yolsuzluklar da artmış olup; suç ve suç unsurlarıyla beraber suçun tespit edilerek ortaya çıkartılması da başka bir boyut kazanmıştır. Bilgisayar teknolojilerinin kullanılması bilişim sektörü için önemli faydalar sağlamakla beraber, art niyetli insanlar için de yeni alanlar yaratılmışır. Bu suçları ortaya çıkarmak için alanında uzmanlaşmış, olayın gerek hukuk gerekse de muhasebe boyutunu değerlendirebilecek olan kişilere gereksinim artmıştır. Böylece, ticari hayatta hile ve yolsuzlukların tespitine odaklanmış, avukatlar ve muhasebeciler arasında iletişim sağlayan adli muhasebecilik denilen yeni bir muhasebe disiplini ortaya çıkmıştır (Al, 2014:100-101).

Adli muhasebecilik, ticari alandaki hukuki problemlerin çözümüne ilişkin uygulamaları kapsamaktadır. Adli muhasebeciler, sahip oldukları yetenek, edindikleri mesleki eğitim ve tecrübe ile hile ve yolsuzlukların önlenmesi ve ortaya çıkarılmasında fayda sağlarlar. Gün geçtikçe ekonomik ve ticari hayatın karmaşıkığı artmakta, böylece adli muhasebecilere olan talep de artmaktadır.

Başta ABD olmak üzere diğer batı ülkelerinde yaşanan muhasebe skandalları sonrasında yoğun olarak gündeme gelmiş olan adli muhasebecilik, ülkemizde yeterince ilerleme kaydedememiştir. Bu bağlamda, adli muhasebecilik mesleğine katkı sağlamak adına hazırlanan bu çalışmada, adli muhasebeciliğin kavramsal çerçevesi ortaya konarak meslek tanıtılmaya ve mesleğin geleceğine yönelik değerlendirmeler yapılmaya çalışılmışıı.

\section{Adli Muhasebe ve Adli Muhasebeci Kavramları}

Adli muhasebe, yeni bir kavram olması sebebiyle dünya genelinde kabul edilmiş standart, kesin bir tanımı yoktur. Ancak sınırlayıcı olsa da kavrama ilişkin bazı ortak tanımlamalar yapılmıştır. Bunlardan bazıları aşağıdaki gibidir:

Adli muhasebe, "Mahkemeye intikal etmiş veya henüz etmemiş ancak hukuksal bir çatışma yaratması muhtemel konunun esaslı bir boyutunu muhasebe ile ilişkili itilafların oluşturduğu, psikoloji, suç bilimi gibi diğer bilim dallarından da yararlanan kendine has araştırma, sorgulama ve analiz teknikleri kullanarak gerçeği arayan bir bilim dalıdır" olarak tanımlanabilir (Gülten, 2010: 312).

Bir başka tanımlamaya göre adli muhasebe; ceza hukukundaki, medeni hukuktaki ve hukuk bilimindeki konuları analiz etmek, araştırmak, sorgulamak, test etmek ve incelemek için finans, muhasebe, vergi ve denetim bilgisini kullanan bir bilim dalıdır (Dönmez ve Çavuşoğlu, 2015: 48).

AICPA' ya göre adli muhasebe; adli muhasebecinin sahip olduğu muhasebe, denetim, vergi ve diğer alanlardaki bilgi ve araştırmacı yeteneklerinin dava aşamasındaki hukuki problemlerin çözümünde kullanılmasıdır (Huber, 2012: 269).

Adli muhasebe; muhasebe, denetim, hukuk, sayısal yöntemler, finans, bilgisayar teknolojileri vb. alanlarda bilgi ve beceri sahibi olmayı gerektiren ve adli alanda kanıt oluşturacak nitelikteki bilgi ve belgeleri toplayarak, analiz etme ve değerlendirmeyi kapsayan çok yönlü bir disiplin olarak karşımıza çıkmaktadır (Al, 2014:102).

Bu kapsamda adli muhasebecilik, adli yargı kurumlarının kararlarına yardımcı olmak üzere, muhasebe ve finans alanlarında ortaya çıkan anlaşmazlık ve uyuşmazlıkların çözüme kavuşturulması için, özellikle, ticarî davalarda muhasebe ve hukuk arasında bir köprü görevi görmektedir (Bekçioğlu, Coşkun ve Gümüş, 2013: 4)

Yukarıdaki tanımlardan da yola çıkarak adli muhasebenin sahip olduğu özellikleri aşağıdaki gibi sıralayabiliriz (Terzi ve Şen, 2015: 479):

- $\quad$ Adli muhasebe, hem toplumsal hem de mesleki faaliyetlerdir,

- $\quad$ Adli muhasebe, özellikli yasal konularda toplumu da ilgilendiren mesleki faaliyetlerdir, 
- Adli muhasebenin mesleki faaliyetleri; hukuk, muhasebe, denetim, değerleme gibi çok çeşitli alanlarla birlikte hareket etmektedir,

- Adli muhasebenin mesleki faaliyetleri, toplumsal mülkiyet haklarını korumayı amaçlamaktadır.

Ali muhasebe mesleğini uygulayan kişi ise dilimize "Adli Muhasebeci" olarak çevrilebilmektedir.

ACFE' ye göre adli muhasebeci, muhasebe bilgisini araştırmacı yetenekleri ile birleştirip, bu bilgi ve becerilerini dava desteğinde ve araştırmacı muhasebecilik alanında kullanan uzman kişidir (Dönmez ve Çavuşoğlu, 2015: 48).

Adli muhasebecilerin en sıklıkla görev aldığı davalar hilenin araştırılması ve soruşturulmasına ilişkin davalardır. Bunun dışında, boşanma davaları, iflas davaları ve vergi davalarında da görev alarak yasal sisteme yardımcı olmaktadırlar (Curtis, 2008: 535).

Adli muhasebeciler rakamların arka planındaki gerçekleri tespit etmeye yönelik olarak eğitilirler. Karmaşık finansal ve finansal olmayan işlemlerin analizi, yorumlanması, özetlenmesi ve sunumu adli muhasebe mesleğinin öne çıkan özellikleridir. Bir adli muhasebesi aynı zamanda yasal kavram ve prosedürleri de iyi bilmelidir. Bunların dışında, adli muhasebeciler tarafından yerine getirilen temel faaliyetler aşağıdaki gibidir (Bhasin, 2007: 1002):

- $\quad$ Finansal kanıtların incelenmesi ve analiz edilmesi,

- Finansal kanıtların analizi ve sunumuna yardımcı olacak yazılım ve programların geliştirilmesi,

- Bulguların rapor, doküman şeklindeki belgeler halinde sunulması,

- Dava kanıtlarını desteklemek için görsel belgeler sunarak ve mahkemede uzman şahit olarak tanıklık ederek yargılama sürecine yardımcı olmak.

\section{Adli Muhasebeciliğe Duyulan İhtiyaç}

Batı ülkelerinde 1980'li yıllardan sonra işletmeler, avukatlar, mahkemeler ve diğer kamu kurumları aşağıdaki sorunların çözümünde destek alacakları bir mesleğe ihtiyaç duymuşlardır (Bozkurt, 2000: 56):

- Toplumda bireyler ve kurumlar artan oranda mahkemelere başvurmaya başlamıştır,

- Ticari işlemler giderek karmaşıklaşmaktadır,

- $\quad$ Toplumda, bireyler ve kurumlarla devletin ilişkileri giderek sorun doğurmaya başlamıştır,

- Işsletmelerde çalışanların yaptıkları yolsuzluklar giderek artmakta ve ortaya çıkartılması ve de önlenmesi zorlaşmaktadır,

- $\quad$ Artan sayıda ve büyük tutarlarda işletme başarısızlıkları yaşanmaktadır,

- $\quad$ Avukatlar ve mahkemeler karşılaştıkları olaylarda daha fazla uzman desteğine gerek duymaktadırlar.

Yukarıda sıralanan sebeplerden dolayı 1980'li yıllardan itibaren başta ABD olmak üzere gelişmiş batı ülkelerinde muhasebe ve denetim alanında "Forensic Accounting", ülkemizde ise "Adli Muhasebecilik" olarak adlandırılan yeni bir meslek dalı doğmaya başlamıştır.

Adli muhasebecilik mesleğini gerektiren temel nedenler; işletmelerin, devletin, kanun koyucularının ve mahkemelerin bilgi teknolojilerindeki hızlı değişime ayak uydurabilecek, ileri düzeyde yapılan mali, hata ve hileleri ortaya çıkaracak uzmanlara olan ihtiyaçtır. Bu ihtiyaç, hilelerin "Niçin" yapıldığından ziyade, "Nasıl" yapıldığını tespit etmeye yöneliktir. Bu doğrultuda, adli muhasebeci mesleki bilgisini ve ussal araştırma yöntemlerini bir arada kullanarak; problemlerin çözümü ve adaletin sağlanmasına yardımcı olmaktadır. Etik dışı davranışların artması, muhasebe öğretisinin yetersizliği, bilirkişilerin odaklanma noktalarındaki farklılıklar, bilirkişi müessesinin yetersizliği, hukuk fakültelerinde verilen mali eğitimin yetersizliği, hata ve 
hilelerin ortaya çıkarılmasındaki güçlükler adli muhasebeye olan ihtiyacın temel belirleyicileri olmuşlardır (Açık, 2016: 1074-1075).

ABD'de 2002 yılında yürürlüğe giren Sarbanes- Oxley yasası ile bağımsız denetim alanında "Public Company Accounting Oversight Board" adlı yeni bir gözetim ve denetim kurulu oluşturularak, bağımsız denetim hizmeti verecek kuruluşların bu kurula kaydı zorunlu tutulmuştur. Sarbanes-Oxley yasası ile şirket yöneticilerine iç kontrol sistemini inceleme ve denetleme, şirket CEO ve CFO' larına da mali tabloları onaylama yükümlülüğü getirilmiştir. Ayrıca, bu yasa şirketlere mevcut kurulların dışında bir denetim komitesi bulundurulmasını zorunlu tutmuştur. Yönetim kurulunun bir alt komitesi olacak olan denetim komitesi, denetim firmasının atanması ve çalışmasının gözetiminden, (yönetim ile denetmen arasındaki mali raporlarla ilgili anlaşmazlıklar dahil) denetim raporunun veya ilgili çalışmanın hazırlanması veya sunulması hizmetlerinden doğrudan sorumlu olacaktır. Denetim firmaları da raporlarını doğrudan denetim komitelerine vereceklerdir (Pazarçeviren, 2005: 3).

\section{Adli Muhasebecilik Mesleğinin Kapsamı}

Adli Muhasebecilik, birçok endüstri sahasını içine alan, geniş bir soruşturma alanına sahiptir. Yargıya intikal etmiş konular muhasebe bilgi ve becerisi kullanılarak çözülmeye başlanmıştır. Adli muhasebeci, yapmış olduğu analizlerle olaylara ışık tutarak sorunların çözümüne ve adaletin yerini bulmasına yardımcı olmaktadır (Aktaş ve Kuloğlu, 2008: 110).

Adli muhasebe mesleğinin kapsadığı faaliyet alanları aşağıdaki gibi üç bölüme ayrımaktadır (www.forensic-accounting-information.com/forensic-accounting-careers.htm, Erişim Tarihi: 31 Aralık 2016):

- Dava Desteği,

- Hile Denetçiliği (Araştırmacı Muhasebecilik),

- Uzman Şahitlik.

\section{Dava Desteği}

Bu alanda adli muhasebeci, adli dava öncesinde veya dava aşamasında hukuki problemlerin çözümünde hukukçulara yardımcı olmaktadır (Toraman, Abdioğlu ve İşgüden, 2009: 37). Adli muhasebeci faydalı, güvenilir ve ilgili bilgiyi değerlendirir, finansal veriyi toplar, analiz eder ve bu konuda görüsünü içeren bir rapor hazırlar. Ayrıca adli muhasebeci yeminli tanık olarak soruları hazırlar, sorgulamayı yönlendirir (Elitaş, 2012: 158).

Genel olarak bir adli muhasebeci aşağıdaki konularda dava desteği sağlamaktadır (Özkul ve Özdemir, 2010: 156):

- $\quad$ Bir iddiayı reddetmek veya desteklemek için gerekli olan belgeleri sağlamak,

- $\quad$ Eksik noktaları tespit etmek ve durumun bir ön değerlendirmesini yapmak için belgeleri incelemek,

- Finansal durumun anlaşılması ve gelebilecek iddialara karşı savunma hazırlanması,

- Karşı taraftaki bilirkişinin zarar talebi raporunu incelemek ve mevcut durumun eksik ve iyi yönleri hakkında raporları gözden geçirmek,

- Davanın sonuçlanmasına yönelik görüşme ve tartışmalara yardımcı olmak.

\section{Hile Denetçiliği (Araştırmacı Muhasebecilik)}

Adli muhasebecilik mesleğinin en temel konusu hile ve yolsuzluklarının ortaya çıkarılmasıdır. Bu sebeple, gerek yürütülen bir soruşturma kapsamında gerekse işletmelerin önlem almalarını sağlamak amacıyla yapılan hile ve yolsuzluk araştırmaları adli muhasebe uygulamalarının önemli bir bölümünü oluşturmaktadır (Çabuk ve Yücel, 2012: 34).

Hile denetçiliği, mali verilerin doğruluğundan ve güvenilirliğinden şüphe duyulması durumunda başvurulan adli muhasebe uzmanlık alanıdır. Bu bağlamda, hile denetçiliği veya araştırmacı muhasebecilik hizmetleri, 
yalnızca hile ve yolsuzlukların ortaya çıkmasından sonraki faaliyetleri değil, aynı zamanda bu tür olaylar henüz vukuu bulmadan önce yapılması gereken faaliyetleri de kapsar. (Ferhan ve Uyar, 2015: 182)

Günümüzde, işletme çalışanları, tepe yöneticileri ve bireyler tarafından çok sayıda, çeşitli alanlarda ve biçimlerde hileler yapılabilmektedir. Bu hilelerden bazıları (Bozkurt, 2000: 63):

- Iş̧letme çalışanları tarafından yapılan hileler,

- Beyaz yakalılar tarafından işlenen suçlar,

- İşletme tepe yöneticilerinin işletme ilgililerini yanıltmaya yönelik olarak yaptıkları mali tablo hileleri,

- Yatırımlarla ilgili hileler,

- $\quad$ Ticari rüşvetler ve komisyonlar,

- $\quad$ Banka işlemleri ile ilgili hileler,

- $\quad$ Elektronik fon transferleri ile ilgili hileler,

- $\quad$ Kredi kartı hileleri,

- Bilgisayar hileleri,

- Internet yoluyla yapılan hileler.

\section{Uzman Şahitlik}

Adli muhasebeci, mahkemede uzman şahit olarak, duygusallıktan uzak ve sakin bir şekilde, açık ve anlaşılır bir dille, karmaşık muhasebe sorunlarına ilişkin uzman görüşlerini sunar. Diğer bir ifadeyle adli muhasebeciler, uzman şahitlik görevlerini yerine getirirken, tarafsız, bağımsız ve objektif davranmalıdırlar. Mesleki konuları açık ve çözümleyici bir dille ifade etmelidirler (Özkul, 2009: 67).

Adli muhasebecilerin uzman şahitlik faaliyetlerinde üzerlerine düşen görevler aşağıdaki gibi sıralanabilir (Kasap, 2013: 125-126):

- Mahkemeye intikal etmiş ve soruşturma açılmış vaka ile ilgili olarak gerekli araştırmaları yaparak çeşitli bilgi ve belgeleri elde etmek,

- V Vaka ile ilgili elde edilen bilgi ve belgelere bağlı olarak bir sonuca veya bir kanıya ulaşmak,

- Mahkeme heyetine ve avukatlara elde edilen ve bilgilere göre belirlenen sonuçları aydınlatıcı ve öğretici bir biçimde sunmak.

\section{Adli Muhasebecinin Özellikleri}

Adli muhasebeciler, "kayıtların görünen değerini kabul etmeyip arka planına bakan, dokümanlar hakkında şüphe duyan, gerçek niyeti araştıran, bilirkişi raporu hazırlayan, özellikle birilerinin yalan söyleme intimalinin olduğu durumlarda ortaya çıkan, bireylerle çok detaylı mülakatlar yaparak gerçeği ayrıntılarıyla ortaya koyan kişidir" (Akyel, 2009: 85).

Bir adli muhasebecinin yapısında barındırması gereken özellikleri aşağıdaki gibi sıralayabiliriz (Bozkurt, 2000: 60):

Merak: Adli muhasebeci, mesleki alanda ilgili ve merakı olmalıdır. Faaliyetlerinde mesleki şüpheciliğini kullanmalıdır.

Israrcılık: Adli muhasebeci, üzerine aldığı işi tümüyle tamamlayana kadar araştırmalarını sürdürmelidir.

Yaratıcılık: Adli muhasebeciler, uymak durumunda oldukları ilke ve standartlar yanında olabildiğince yaratıcı olmalı, ayrıntılara dikkat etmelidirler. 
Sezgi: Adli muhasebeciler, her durumu kendi özelliklerine göre araştırmalı, olayı hem bir resim gibi genel olarak hem de ayrıntıları ile analiz etmelidirler. Baskı ortamında sakin davranmalı, iyi bir işletme sezgisine sahip olabilmeli, kararlarında net, analitik ve mantıki bir düşünceyi hakim kılmalıdır.

Hüner: Bir adli muhasebeci, tüm çalışmalarına sunmak amacıyla yazılı veya sözlü iletişimde başarılı olmalıdır. İnsan ilişkilerini sağlıkı bir biçimde kurabilmelidir.

Yukarıdaki karakteristik özellikleri taşımanın yanında, adli muhasebecilerin muhasebe dışındaki diğer alanlarda da bilgi sahibi olması gerekir. Bu alanları aşağıdaki gibi sıralayabiliriz (Karacan, 2012: 116):

$\begin{array}{ll}\text { - } & \text { Yoğun bir muhasebe bilgisi } \\ \text { - } & \text { Denetim } \\ \text { - } & \text { İstatistik } \\ \text { - } & \text { Hilgisayar uygulamaları } \\ \text { - } & \text { Psikoloji } \\ \text { - } & \text { Araştırma teknikleri } \\ \text { - } & \text { Suç bilimi } \\ \text { - } & \text { Işletme yönetimi }\end{array}$

\section{Adli Muhasebecilik Hizmetinin Aşamaları}

Her adli muhasebe görevi kendine has olduğundan, uygulanacak işlem ve izlenecek yollar da farklılık gösterecektir. Bununla birlikte, genel olarak bir adli muhasebe işlemi aşağıdaki aşamaları kapsar (Bekçioğlu, Coşkun ve Gümüş, 2013: 11-12; Kasum, 2009):

Müşteriyle Buluşma: Bu işlem mevcut durumun tespit edilmesi, olayın içindeki tarafların ve sorunların anlaşılması açısından önemlidir.

Çatışmanın Tespiti: Taraflar belirlenir belirlenmez, uyuşmazlığa neden olun konu belirlenmelidir.

Başlangıç Araştırması: Ayrıntıı bir eylem plânı yapmadan önce, ön bir araştırma yapılmalıdır.

Bir Eylem Plânı Hazırlanması: Önceki aşamalardan sağlanan veriler kullanılarak, hedefler belirlenmeli ve hedeflere ulaşmak için yararlanılacak yöntem tespit edilmelidir.

Doğru Kanıtların Elde Edilmesi: Davanın niteliğine göre, ilgili belgeler tespit edilmeli, rakamsal veriler, işletme varlıkları, kanıtlar, bilirkişi raporları incelenmelidir. Bu aşamada banka hesap mutabakatları, yevmiye defterleri, defterî kebir, veri tabanları ve müşterinin malî durumuna ilişkin diğer kayıtlar ayrıntıı incelenecektir.

Analiz: Davanın niteliğine göre, grafik ve tablo yardımıyla malî kayıplar hesaplanır, işlemler özetlenir, aktifler izlenir, şimdiki değer hesapları yapılır.

Raporun Hazırlanması: Rapor, yapılan işlemin içeriğine, araştırmanın boyutuna, uygulanan yaklaşım ve metotlara, ortaya çıkan bulgulara göre, çeşitli bölümler halinde hazırlanır.

\section{Adli Muhasebecilik Eğitimi ve Meslek Mensubu Olma}

\section{Dünyadaki Uygulamalar}

Dünyadaki örneklerine bakıldığında adli muhasebecilik mesleğini uygulayan ülkelerde, adli muhasebe eğitimi muhasebe eğitiminden bağımsız değildir. Şekil 1'de görüldüğü gibi adli muhasebe ile muhasebe denetimi ve hile denetimi arasında sıkı bir ilişki vardır. 


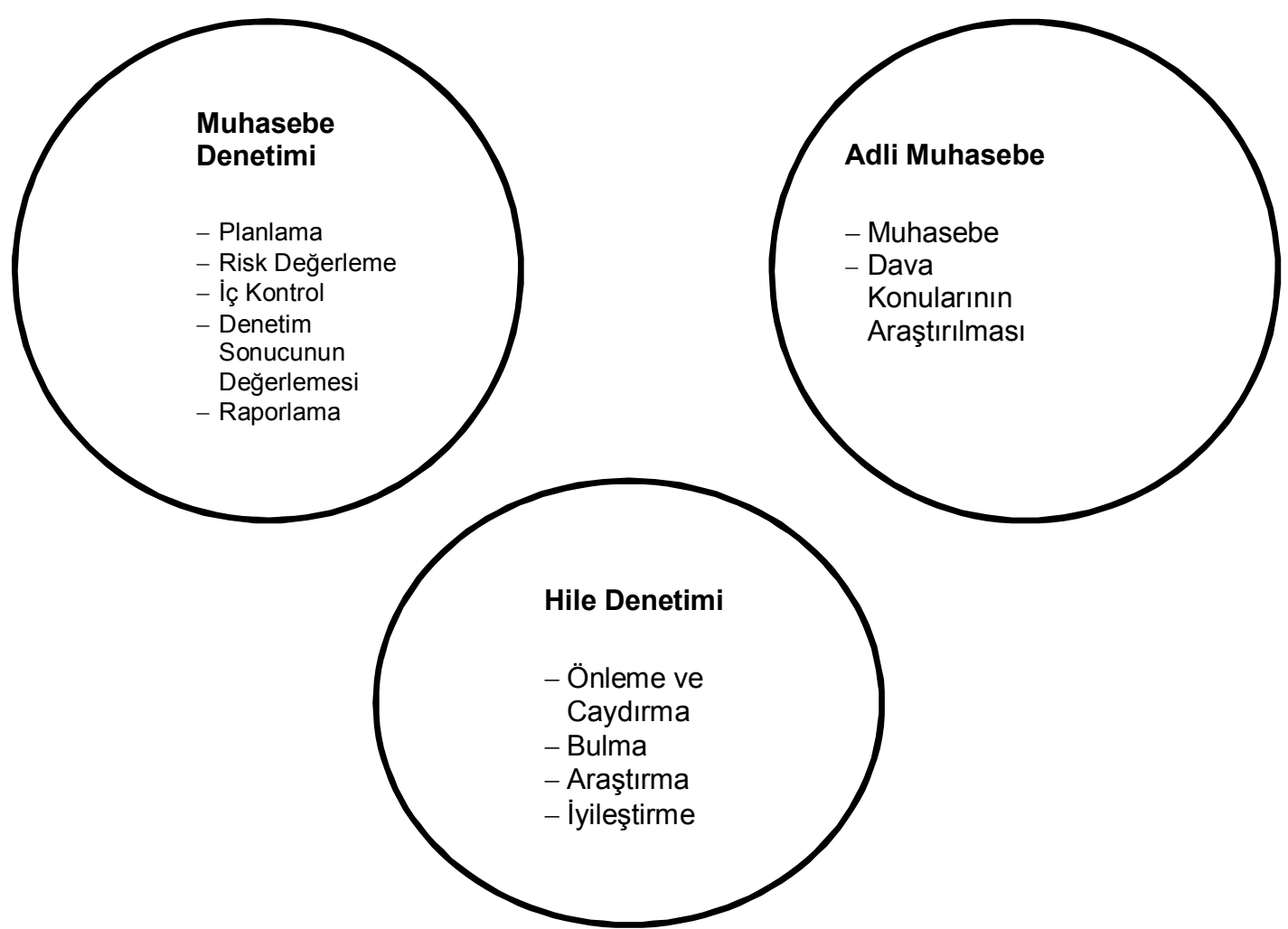

Şekil 1. Adli Muhasebe, Muhasebe Denetimi ve Hile Denetimi Arasındaki Iliş̧i

Kaynak: Kranacher, Morris, Pearson ve Riley, 2008: 509

Adli muhasebeci adayları, almış oldukları eğitimin desteğiyle inceleme, araştırma, analitik düşünebilme ve bunların sonucunda doğru şekilde yorumlayabilme becerisine sahip olurlar. Bu sebeple adli muhasebeciler açısından; muhasebe teorileri, denetim, yönetim bilimi, işletme bilimi, iç kontrol sistemi, halkla ilişkiler, iletişim sistemleri, hile denetimi, temel bilgi teknolojileri, istatistik, psikoloji, sosyoloji ve kriminoloji gibi çok çeşitli alanlarda alınan eğitimin önemi oldukça büyüktür (Usul ve Topçuoğlu, 2011: 62).

Yukarıda da açıklandığı gibi adli muhasebecilerin sahip olması gereken özellikler ve eğitim bilgisi diğer muhasebe meslek mensuplarının sahip olması gerekenlerden daha kapsamlı ve detaylıdır. Bu nedenle dünyadaki uygulamalarına bakıldığında mesleğin gelişmesi yönünde çok sayıda düzenleme yapıldığı görülmektedir. Başta $A B D$ olmak üzere diğer batı ülkelerinde adli muhasebecilik eğitimi bünyesinde birçok eğitim programı düzenlenmiştir.

Adli muhasebecilikte eğitimle birlikte tecrübe de oldukça önemlidir. Örneğin ABD'de belgeli bir adli muhasebeci olabilmek için aşağıda belirtilen aşamalardan geçilmesi gerekmektedir (Bozkurt, 2000: 60-61):

- Lisans eğitimi,

- İki yıl süreyle mesleki deneyim,

- $\quad$ ABD'de faaliyet gösteren “Diplomalı Hile Araştırmacıları Kuruluşu (Association of Certified Fraud Examiners-ACFE)" nun sınavlarında başarılı olmak. 
Ortalama 25.000 kayıtlı meslek mensubu bulunan ACFE, adli muhasebecilik ve hile denetçiliği konularında faaliyet gösteren kurumlar arasında en önemlisi olarak kabul edilmektedir. ACFE, adli muhasebecilik ve hile denetçiliği alanlarında önemli hizmetler vermekte, eğitim ve seminerler düzenlemektedir. Kurum tarafından yapılan mesleki sınavlar aşağıdaki dört ana bölümden oluşmaktadır (Bozkurt, 2000: 61)

- $\quad$ Finansal işlemler,

- $\quad$ Araştırmacılık,

- Yasal unsurlar ve

- $\quad$ Suç bilimi

ACFE yanında mesleğin belli ölçülerde standardizasyonunu sağlamak üzere kurulan, yaptıkları çeşitli çalışmalarla mesleğe katkı sağlayan diğer kurumlar aşağıdaki gibidir (Karacan, 2012: 123):

- $\quad$ The Canadian Institute of Chartered Accountants-CICA

- $\quad$ The Chartered Accountants-CA

- $\quad$ National Association of Certified Fraud Examiners-CR-NACFE

- $\quad$ National Association of Forensic Accounting-NAFA

Birçok adli muhasebeci bu mesleği profesyonel anlamda yerine getirebilmek için Yeminli Hile Müfettişi (CFE) veya Sertifikalı Kamu Muhasebecisi (CPA) gibi mesleki belgeler edinmektedirler. Bu tür belgelerin verilmesi için yukarıda sıralanan çeşitli kurum ve kuruluşlar ile üniversiteler devreye girmiştir. Örneğin, Florida Atlantik Üniversitesi'nde adli muhasebeye ilişkin lisansüstü programlar mevcuttur (Pazarçeviren, 2005:13).

\section{Türkiye'deki Uygulamalar}

Türkiye'de adli muhasebecilik mesleğine yönelik yasal bir düzenleme mevcut değildir. Ancak mesleğin kapsamına giren faaliyet alanlarına yönelik bu görevi yerine getiren meslek grupları bulunmaktadır. Tablo 1 'de bu meslek grupları ve meslek mensubu olma süreçleri verilmiştir. 
Tablo 1. Türkiye'de Adli Muhasebe Mesleği Kapsamında Düzenleme Yapan Kuruluşlar ve Meslek Unvanları

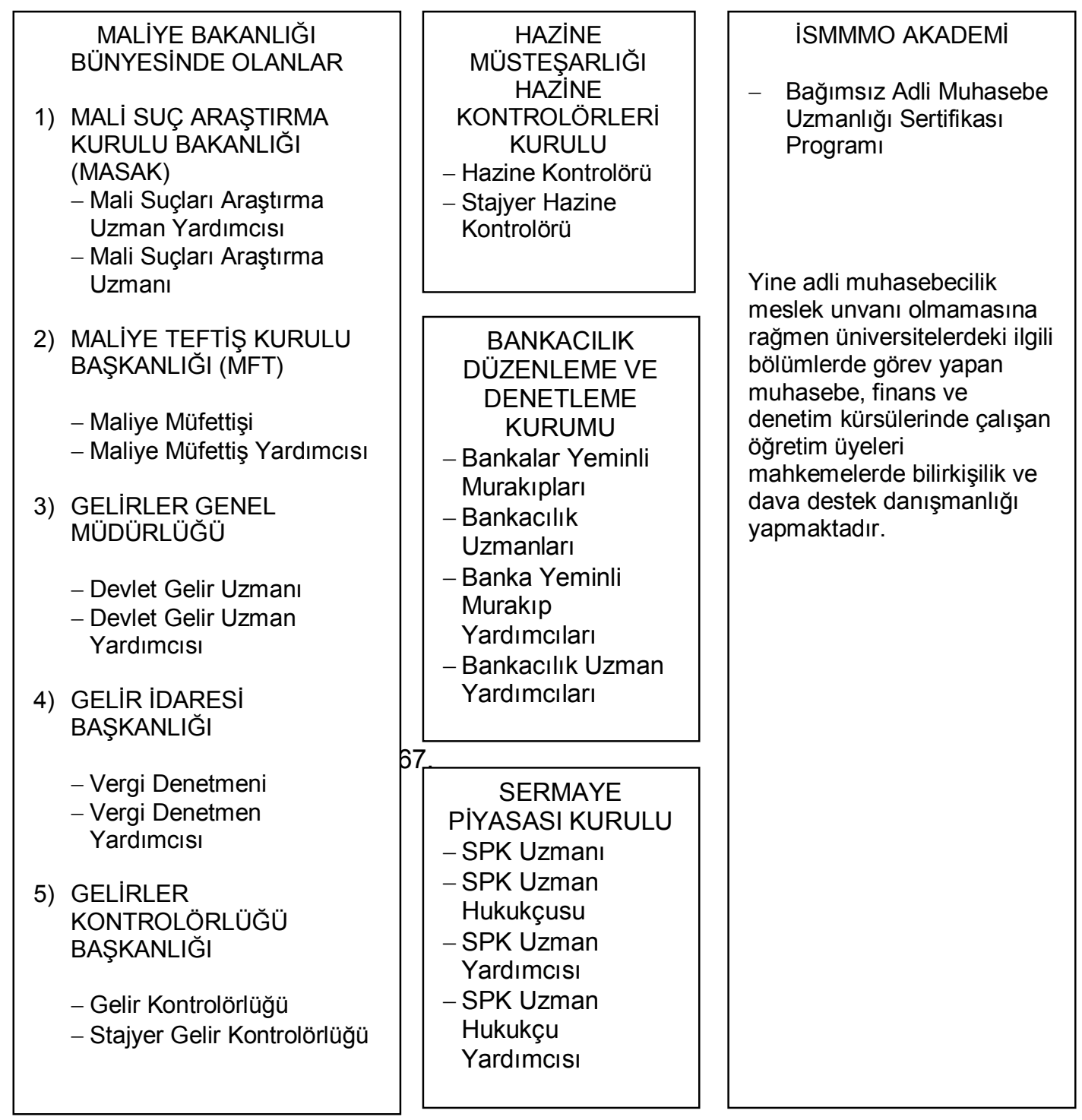

Kaynak: Kurt ve Uçma, 2009: 167.

Yukarıda da açıkça ifade edildiği gibi, ülkemizde adli muhasebecilik mesleğinin doğrudan bir uygulaması bulunmamaktadır. Ancak, Maliye Bakanlığı başta olmak üzere birçok kurumun bu meslek alanına ilişkin düzenlemeleri bulunmaktadır. Burada dikkat edilmesi gereken nokta, alınan meslek unvanlarının hiçbirinde muhasebe meslek mensubu olma şartı aranmamasıdır. Bu doğrultuda, ülkemizde adli muhasebecilik mesleği kapsamında meslek unvanları bulunmakta ancak uluslararası anlamda adli muhasebecilik mesleğine ilişkin yasal düzenlemelerin yapılmadığını söylemekte fayda bulunmaktadır.

Ülkemizde adli muhasebecilik mesleğinin eğitim boyutunu irdelediğimizde; yüksek öğretim kurumları tarafından bu alana ilişkin ön lisan, lisans, yüksek lisans ve doktora düzeylerinde bir eğitim verilmemektedir. Ancak İstanbul Serbest Muhasebeci Mali Müşavirler Odası'nın (ISMMMO) düzenlemiş olduğu "Bağımsız Adli Muhasebe Uzmanlığı" eğitimi adında bir sertifika programı bulunmaktadır. Bu sertifika programı kapsamında meslek mensubu adaylarının alacakları eğitimle araştırmacı muhasebeci ve hile denetçiliği alanlarında çalışmaları hedeflenmektedir. 
ISMMMO haricinde, adli muhasebecilik alanında verilen diğer bir eğitim de Bahçeşehir Üniversitesi "Adli Muhasebecilik Uzmanlığı" sertifika programıdır. Üniversite bünyesinde verilen sertifika programı kapsamında, adli muhasebecilik alanında dünyadaki yeni gelişmelerin takip edilmesi, hile, suistimal ve dolandırıcılıkların önlenmesi konularında uzman olmak isteyenlere temel bilgi ihtiyaçlarının kazandırılması amaçlanmaktadır (Keleş ve Keleş, 2014: 70).

\section{Adli Muhasebecilik Mesleğinin Geleceği}

1980'li yıllar sonrasında Enron, Worldcom, Xerox, Parmalat vb. gibi şirketlerde yaşanan skandallar finansal tablolara olan güveni azaltmıştır. Skandallara sebep olan hile ve yolsuzlukların önlenmesinde geleneksel yöntemler yetersiz kalmışıı. Bu skandalları önleme çabaları başta ABD olmak üzere diğer gelişmiş batı ülkelerinde adli muhasebe olarak adlandırılan yeni bir uzmanlık alanının gelişmesine ortam hazırlamıştır.

30 Temmuz 2002'de Amerika'da yatırımcının finans piyasalarına, kurumsal yönetime ve finansal raporlamaya duyduğu güvenin onarılması için dönüm noktası olarak kabul edilen Sarbanes-Oxley Kanunu çıkartımıştır. Bu kanun ile denetim şirketlerinin hâlihazırda verdikleri bazı hizmetlerin, adli hizmetler kapsamında olduğu, dolayısıyla bu hizmetlerin adli muhasebeci tarafından verilmesinin gerekliliği ortaya konmuştur (Özkul ve Özdemir, 2010: 159).

Günümüzde muhasebe ve denetim alanları gayet açık ve net bir şekilde tanımlanmış olsa da adli muhasebe konusu henüz emekleme aşamasındadır. Adli muhasebecilik mesleğinin geleceğine ilişkin yapılacak değerlendirmede aşağıdaki unsurlar gözden geçirilmelidir (Akyel, 2009: 112):

Mali tabloların denetlenmesi ve adli muhasebe arasındaki sınırlar dikkate alınarak bu disiplinin kendi içerisinde değerlendirilmesi,

Yeni kuşak adli muhasebe araştırmacılarının eğitimi ve yetiştirilmesi,

Yasal çevre ve düzenlemelerdeki değişiklikler,

Araştırma yapılması kararı, araştırma süreci ve araştırma sonuçlarının gerçekçi kar ve maliyet hesaplarıyla değerlendirildiği değişen şirket ortamları,

Hile manipülasyonu gibi görülebilecek finansal olmayan işlevsel veriler açısından şirket raporlamalarında meydana gelen değişiklikler.

Yukarıdaki unsurlara ilişkin açıklamalara aşağıda yer verilmiştir.

\section{Gelişen Adli Muhasebe Disiplini}

Adli muhasebe faaliyetinin daha iyi anlaşılması için, bu konuda hizmet veren kişilerin (çeşitli hizmetler veren firmaların, şirket yöneticilerinin ve avukatların) birlikte çalışarak hızı bir şekilde sağlam bir politika oluşturmaları gerekmektedir. Gelecek 5-10 yıl içerisinde adli muhasebe disiplini kapsamında alt uzmanlık alanlarının gelişeceği düşünülmektedir. Bu uzmanlık alanlarının muhtemelen endüstri odaklı olması beklenmekte ve bunun için de bu alanda çalışanların sayısının artması gerektiği vurgulanmaktadır. ABD' de 336.000 belgeli/izinli muhasebeci bulunurken, bu grup içerisinde yetkili Hile Araştırmacılarının sayısı yalnızca $\% 5$ oranındadır.

Dijital ortamın ve network ağlarının gelişmesi adli muhasebenin gelişimine de katkı sağlayacaktır. Örneğin alt uzmanlık dallarından biri, "veri toplaması" olabilir. Verilerin toplanması objektif bir tarzda yapılmamışsa, veri analizi objektiflikten uzaklaşabilecektir. Günümüzde veri toplanması ve yorumlanması, gerçekte muhasebe sistemlerinden anlayan personellerden oluşturulmuş takımlarca geçekleştirilir. Bu kişiler, nerede neyi arayacaklarını, yolsuzluk araştırmasındaki kritik noktaları nasıl bulacaklarını ve elde ettiklerini nasıl yorumlayacaklarını çok iyi bilmektedirler. 


\section{Yeni Disiplini Destekleyecek Mesleki Eğitim ve Yetiştirme}

Son yıllarda yaşanan gelişmeler sonucunda bir ihtiyaç olarak ortaya çıkan adli muhasebecilik; öncelikle çok sağlam bir muhasebe bilgisine, bunun yanı sıra, denetim, risk değerlendirme, kontrol ve hile denetimi bilgisine ayrıca hukuk ile ilgili temel bir bilgi setine sahip olmayı zorunlu kılmaktadır. Bunlardan birinin eksik olması adli muhasebe bilgisinin eksik olması anlamına gelmektedir (Pehlivan, 2010: 51).

Bu sebeple, üniversiteler, ilgili bir program açamıyorlarsa bile, en azından, adli muhasebe ile ilgili derslerin işletme, kriminoloji ve hukuk gibi programların içinde yer almasını sağlayabilirler. Ayrıca, sorunun değişik disiplinleri ilgilendirmesi, ideal bir adli muhasebe eğitimi programı hazırlanırken, farklı disiplinlere mensup olanların bir araya gelerek araşııma takımları oluşturmasını da zorunlu hale getirmektedir. Aksi durumda, her disiplin, sorunun sadece kendini ilgilendiren boyutunu ele alarak, çözümü daha dar bir çerçevede ele almak durumunda kalacaktır (Pehlivan, 2010: 53).

Rezaee vd. tarafından Amerika' da adli muhasebe eğitimine verilen önemi belirlemek amacıyla hem akademisyenlere hem de uygulayıcılara yönelik bir anket çalışması yapılmıştır. Adli muhasebenin gelecekteki yönünü ve rolünü belirlemede oldukça önemli olan bu çalışmanın sonuçları (Rezaee, Crumbley ve Elmore, 2004: 23):

- $\quad$ Adli muhasebeye olan talep ve ilginin gelecekte daha fazla artması beklenmektedir.

- Daha fazla sayıdaki üniversite adli muhasebe eğitimini vermeyi planlamaktadır.

- Verilecek olan adli muhasebe eğitiminin öğrenciler için oldukça faydalı olacağı düşünülmektedir.

- $\quad$ Adli muhasebe eğitiminde öncelikle verilmesi gereken temel konular seçilerek bunların muhasebe eğitimi ile entegrasyonu sağlanmalıdır.

\section{Diğer Yasal Gereklilikler ve Borsayla İlgili Koşullar}

ABD'de Enron sonrasında sermaye piyasasında yatırımcıları korumak amacıyla, 30 Temmuz 2002 tarihinde Sarbanes-Oxley Yasası çıkarılarak halka açık şirketlerin denetiminde yeni bir düzen ve disiplin sağlanması amaçlanmıştır. Denetimde bağımsızıı ve etkinlik sağlayarak finansal yatıııcıların korunmasını amaçlayan yasa, menkul kıymetler yasalarına yeni hükümler ile denetimde bağımsızlığı engellemeye ve yatırımcıları yanıltmaya yönelik suçlara büyük yaptırımlar getirmektedir. Yasanın getirdiği en önemli yenilik, denetimde etkinlik ve bağımsızlığı sağlamak amacıyla denetim faaliyetlerinin gözetimi ve denetimi ile görevli bir üst kurul oluşturulmasıdır. Sarbanes-Oxley Yasası, denetçi rotasyonu, denetim dışı hizmetlerin sınırlanması, çıkar çatışması durumunda denetim firmasına denetleme yasağı getirilmesi ve şirket yönetiminin denetçi üzerinde baskı kurmasını önlemeye yönelik olarak yaptırımların ağırlaştırııması yoluyla denetçi bağımsızı̆̆ını sağlamayı amaçlamaktadır (Coşkun, 2013: 58).

ABD Borsa Yasası gerçeklerle ilgili yanlış ifadelerde bulunmayı ya da gerçeği/sonuçları etkileyecek gerçekleri saklamayı yasaklamaktadır. Bu yasaklamanın kapsamı hem finansal hem de finansal olmayan bilgileri içerisine almaktadır. Benzer şekilde Sarbanes-Oxley Yasaları'nın 302 No.lu maddesi üst düzey yöneticilerin, gerekli finansal ve finansal olmayan bilgilerin üçer aylık ve yıllık raporlarda verilmesi ve iç denetimlerde bunların gözden geçirilmesi konusunda yükümlü olduğunu belirtmektedir. Tüm endüstri kollarında finansal olmayan iş verileri ile ilgili titiz incelemeler yapılması gerektiğinde adli muhasebe araştırmacılarına olan talep çok daha fazla olacaktır (Akyel, 2009: 115).

\section{Yeni Araçlar}

Başarıı hile veya adli muhasebe araştırmalarında dijital ortamın kullanılmasının yararları henüz yeteri kadar anlaşılabilmiş değildir. Oysa dijital ortam, hem kanıtın tespitinde, hem kanıtların depolanmasında, hem de işlenmesinde oldukça önemli yararlar sağlayabilmektedir. (Pehlivan, 2010: 63-64). 
Mevcut koşullarda elle tutulan muhasebe kayıtları ile yolsuzluğun önlenmesi mümkün değildir. Hile tarama ve önlemenin yanında yolsuzlukları da en aza indirmek için veri madenciliği ve yapay zekâ ile istatistik gibi sistemleri modelleyebilen programlardan faydalanılmaktadır. Yolsuzlukla mücadele kapsamında, veri madenciliği analizleri, özet ve raporlarla, her yıl dünya çapında milyar dolarları bulan mali kayıpların önüne geçilebilmektedir. Veri madenciliği, adli muhasebecilik uygulamalarına sağlamış olduğu bu faydalar nedeniyle, bilgi teknolojileri içerisinde ayrı bir öneme sahiptir (Coşkun, 2013: 62)

Adli muhasebe öğrencilerinin dijital ortam ve bilgi teknolojileri hakkında bilgi sahibi olmaları gerekir. Günümüzde, adli muhasebecililik ve hile araştırmacılığında etkin teknoloji bilgisi ve uygulamaları giderek önem kazanmaktadır. Dolayısıyla, öğrenciler dijital ortamın kolaylaştırdığı çok çeşitli mali ve ekonomik suçların da bilincinde olmalıdırlar (Pearson ve Singleton, 2008: 548).

\section{Sonuç}

Günümüz iş dünyasının yoğun ve karmaşık gündeminde adli muhasebecilik mesleğinin uygulama alanı bulması kaçınılmaz olmuştur. Bu durumun temel nedenleri; gerek çalışan gerekse yönetici düzeyinde yapılan hile ve yolsuzluklar, birey ve işletmeler arasındaki ekonomik ve ticari anlaşmazlıklar ile hukuki anlaşmazlıkların çözümünde uzman desteğine olan talebin artmasıdır.

Adli muhasebecilik alanı 90'ı yılların başından itibaren çeşitli gereksinimlerden yola çıkarak gelişmeye başlamıştır. Gerek kanun gerekse de literatür ve eğitim anlamında yaygın olarak dünya gündeminde yer alsa da ülkemizde gerekli ilgi ve önemi görmemiştir. Bu bağlamda, dünyadaki uygulamalarına bakılarak ülkemizde de gerekli yasal düzenlemeler ve eğitim modelleri için bir alt yapı oluşturulabilir. Çünkü, adli muhasebecilik mesleğinin layıkıyla yerine getirilmesi, hukuki anlamdaki düzenlemeler ve üniversite/mesleki kurumlarda verilen eğitim ve sertifika programları ile mümkün olmaktadır.

Adli muhasebecilik, muhasebenin de ötesinde denetim, istatistik, bilgi işlem, ekonomi, finans, araştırma teknikleri vb. alanlarda da bilgi sahibi olunmasını gerektiren çok yönlü bir disiplindir. Adli muhasebeciler, kayıtların görünen yüzünü değil arka planını araştıran, bunu yaparken de mesleki bilginin yanında merak, ısrar, sezgi, şüphe gibi karakteristik özeliklerle hareket eden alanında uzman kişilerdir.

Sahip olduğu dinamik yapısı ile adli muhasebe mesleğinin gelecek dönemlerde; alt uzmanlık dallarının gelişeceği, adli muhasebe alanında kullanılan araçların (bilgi teknolojileri, yazılım ve programlar vb.) zaman içerisinde gelişme ve ilerleme kaydedeceği, mesleğe ilişkin gerekli yasal düzenlemelerin ve eğitim programlarının yeniden düzenleneceği öngörülmektedir.

\section{Kaynakça}

Açık, S. (2016). Adli Muhasebecilik Mesleğinin Faaliyet Alanları ve Eğitim Boyutu Açısından İncelenmesi, Atatürk Üniversitesi Sosyal Bilimler Enstitüsü Dergisi, 20 (3), Eylül, 1071-1090.

Aktaş, H. - Kuloğlu, G. (2008). "Adli Muhasebe ve Adli Muhasebecilik Mesleği" Muhasebe ve Denetime Bakış, 8 (25), Mayıs, 101-120.

Akyel, N. (2009). Adli Muhasebecilik ve Türkiye'de Uygulanabilmesi İçin Altyapı Bileşenlerinin Mevcut Durumu, Değerlendirilmesi ve Öneriler, Doktora Tezi, Sakarya Üniversitesi, Sosyal Bilimler Enstitüsü, Sakarya.

Al, A. (2014). Adli Muhasebe ve Karar Alma Arasındaki Illişkilerin Finansal Kararlar Açısından Değerlendirilmesi, Mali Çözüm Dergisi, 125, Eylül-Ekim, 95-124.

Bekçioğlu, S - Coşkun, A. - Gümüş, U. T. (2013). İşletmelerde Hile ve Yolsuzlukların Önlenmesinde Farklı Bir Yaklaşım: Adli Muhasebe, Muhasebe ve Finansman Dergisi, 59, Temmuz, 1-16.

Bhasin, M.L. (2007), Forensic Accounting: A New Paradigm for Niche Consulting, The Chartered Accountant, January, published by the ICAI, New Delhi, 1000-1010.

Bozkurt, N. (2000). Muhasebe ve Denetim Mesleğinde Yeni Bir Alan: Adli Muhasebecilik, Yaklaşım Dergisi, Yıl 8, Sayı 94, Ekim, 56-61. 
Coşkun, A. (2013). Adli Muhasebede Farkındalık: Türkiye'deki Bağımsız Denetim Şirketleri Üzerine Bir Araştırma, Doktora Tezi, Adnan Menderes Üniversitesi, Sosyal Bilimler Enstitüsü, Aydın.

Curtis, G.E. (2008). Legal and Regulatory Environments and Ethics: Essential Components of a Fraud and Forensic Accounting Cirriculum, Issues in Accounting Education, Vol: 23, No:4, November, 535543.

Çabuk, A. - Yücel, E. (2012). Adli Muhasebecilik Mesleği ve Türkiye' de Uygulanabilirliğine Yönelik Bir Araştırma, Muhasebe ve Finansman Dergisi, 54, Nisan, 27-50.

Elitaş, B. L. (2012). Seçilmiş Örneklerle Adli Muhasebe Eğitimi ve Türkiye için Bir Değerlendirme", Muhasebe ve Finansman Dergisi, 55, Temmuz, 153-172.

Ferhan, G. - Uyar, Ü. (2015). Adli Muhasebecilik Mesleği ve Mesleğin Dünya'daki Gerekliliği: Worldcom Skandalı, Sosyal Bilimler Dergisi, Yıl: 2, Sayı: 5, Aralık, 178-192.

Gülten, S. (2010). Adli Muhasebe Kavramı ve Adli Müşavirlik Mesleği, Ankara Barosu Dergisi, 68 (3), 311320.

Huber, W.D. (2012). Is Forensic Accounting in The United States Bocoming a Profession?, Journal of Forensic\&Investigative Accounting, Vol.4, Issue 1, 255-284.

Karacan, S. (2012). Hukuk İle Muhasebenin Kesişme Noktası: Adli Muhasebe, Uluslararası Íktisadi ve İdari Incelemeler Dergisi, 4 (8), Kış, 105-128.

Kasap, M. (2013). Adli Muhasebecilik Mesleği ve Aklama Suçuyla Mücadele, Çankırı Karatekin Üniversitesi IiBF Dergisi, Cilt 3, Sayı 1, Bahar, 121-132.

Kasum A. S. (2009), The Relevance of Forensic Accounting to Financial Crimes in Private and Public Sectors of Third World Economies: A Study from Nigeria, Proceedings of The 1st International Conference on Governance Fraud Ethics and Social Responsibility, June, 11-13.

Keleş, D. - Keleş, Ü. (2014). Adli Muhasebecilik Mesleği ve Türkiye'deki Uygulamaları, Gümüşhane Üniversitesi Sosyal Bilimler Elektronik Dergisi, 5 (9), Ocak, 53-75.

Kranacher, M.J.- Morris, B.W. - Pearson, T.A. - Riley, R.A. (2008). A Model Curriculum for Education in Fraud and Forensic Accounting, Issues in Accounting Education, Vol: 23, No:4, November, 505519.

Kurt, G. - Uçma, T. (2009). Adli Muhasebecilik Mesleği ve Adli Muhasebeci Olabilme Sürecinin Türkiye'deki ve Amerika'daki Yasal Düzenlemeler Açısından Karşılaştııılması, Ticaret ve Turizm Fakültesi Dergisi, Sayı:2, 160-178.

Özkul, F.U. - Özdemir, Z.A. (2010). İşletmelerde Hile Riski Yönetimi: Yöneticiler lçin Temel Uygulama Alanları, Beta Yayınevi, İstanbul.

Özkul, F.U. - Pektekin, P. (2009). Muhasebe Yolsuzluklarının Tespitinde Adli Muhasebecinin Rolü ve Veri Madenciliği Tekniklerinin Kullanılması, MÖDAV, 4, 57-88.

Pazarçeviren, S.Y.(2005). Adli Muhasebecilik Mesleği, ZKÜ Sosyal Bilimler Dergisi, 1(2), 1-19.

Pearson, T.A. - Singleton, T.W. (2008). Fraud and Forensic Accounting in The Digital Environment, Issues in Accounting Education, Vol: 23, No: 4, November, 545-559.

Pehlivan, A. (2010). Adli Muhasebe Eğitimi ve Türkiye'de Adli Muhasebe Eğitiminin Geliştirilmesine Yönelik Bir Araştırma, Doktora Tezi, Atatürk Üniversitesi, Sosyal Bilimler Enstitüsü, Erzurum.

Rezaee, Z - Crumbley, D.L. - Elmore, R.C. (2004). Forensic Accounting Education: a Survey of Academicians and Practitioners, Advances in Accounting Education Forthcoming, Available at SSRN: http://ssrn.com/abstract=518263, 1-44.

Terzi, S. - Şen, İ. K. (2015). Adli Muhasebede Hilelerin Tespitinde Yapay Sinir Ağı Modelinin Kullanımı, Uluslararası Íktisadi ve Idari Incelemeler Dergisi, 7 (14), Kış, 477-490. 
Toraman, İ C. - Abdioğlu, İ H. - İşgüden, İ B. (2009). Aklama Suçunun Önlenmesine Yönelik Çabalar: Adli Muhasebecilik Mesleği Ve Uygulamaları, Afyon Kocatepe Üniversitesi I.I.B.F. Dergisi, 11 (1), 1755.

Usul, H. - Topçuoğlu, M. (2011). Finansal Manipülasyonların Ortaya Çıkarılması ve Önlenmesinde Adli Muhasebenin Önemi: Türk Hukuk Sisteminde Var Olması Gerekliliği Üzerine Bir Tartışma. Süleyman Demirel Üniversitesi İktisadi ve Idari Bilimler Fakültesi Dergisi, 16 (3), 53-66.

www.forensic-accounting-information.com/forensic-accounting-careers.htm 